\title{
The examination of self-efficacy beliefs of physical education pre-service teachers according to different variables
}

\author{
Tolga ESKİ ${ }^{1}$, Ayşe Feray ÖZBAL ${ }^{1}$, Arıkan EKTİṘंĊं ${ }^{2}$ \\ ${ }^{1}$ Kastamonu University, School of Physical Education and Sports, Kastamonu, Turkey \\ ${ }^{2}$ Anadolu University, Faculty of Sports Sciences, Eskişehir, Turkey \\ Address Correspondence to T, Eski, e-mail: teski@kastamonu.edu.tr
}

\begin{abstract}
Education is becoming more and more important in today's world. It is also acknowledged that training teachers with high levels of self-confidence in education faculties is likely to improve the quality of education in the future. Bandura (3) proposed the term "self-efficacy" for the first time in 1977 in his book titled Self-efficacy: Toward a Unifying Theory of Behavioral Change. He based this concept on Social Learning Theory and defined it as " one's belief about his/her own ability to acquire a specific behavior successfully". It has been witnessed that self-efficacy beliefs of pre-service teachers affect their perception about students, behaviors, eagerness to learn, experiences and learning outcomes. Thus, this study aims to determine selfefficacy beliefs of pre-service teachers of physical education and sports regarding teaching profession and to examine whether the data obtained vary according to certain variables. The study used survey method. A total of 526 university students (222 female and 304 male) who attend the Physical Education and Sports Teaching Departments of 6 different universities in Turkey participated in the study on a voluntary basis. Developed by the researchers, this form includes questions aiming to obtain the following information about the participants: age, gender, the university they attend, class level, family income level, and educational background of parents. In addition, the study used "Teacher Self-efficacy Scale", which was developed by Tschannen-Moran and Woolfolk Hoy (21) and adapted to Turkish context by Çapa et al. (7). The data was analyzed by using SPSS 22 software and descriptive analysis, independent variable t-test and ANOVA tests were used. There was a meaningful difference in "Student Participation" and "Classroom Management" sub-dimensions in terms of university variable $(p<05)$. Likewise, there was a meaningful difference in "Student Participation" and "Classroom Management" sub-dimensions in terms of mother's educational background variable $(\mathrm{p}<05)$. As a result, meaningful differences were found in variables such as university and mother's educational background. The reason may be that universities took place in different geographical areas of the country. It can be said that the effect of the level of education of the mother on the growth environment is the reason for this difference.
\end{abstract}

Key words: Self-Efficacy Beliefs, Pre-Service Teachers, Physical Education

\section{INTRODUCTION}

Education is becoming more and more important in today's world. It is also acknowledged that training teachers with high levels of selfconfidence in education faculties is likely to improve the quality of education in the future. Therefore, it will be possible to train individuals in schools who are equipped with intrinsic motivation for achievement in their professions, are self-confident and have high levels of job satisfaction. The willingness of teachers to achieve this purpose is highly dependent on to what extent they have professional confidence and self-efficacy beliefs. When teachers are eager and motivated to teach and have high levels of self-efficacy beliefs, this situation will positively affect their academic achievement and professional productivity, which will in turn make it possible to train more qualified individuals in schools. In this sense, it can be concluded that the important role of self-efficacy in training individuals in schools should not be neglected for a better future.

Bandura (3) proposed the term "self-efficacy" for the first time in 1977 in his book titled Selfefficacy: Toward a Unifying Theory of Behavioral Change. He based this concept on Social Learning Theory and defined it as " one's belief about his/her own ability to acquire a specific behavior successfully". Another definition suggested by Senemoğlu (19) states that self-efficacy is "one's selfjudgement about how much successful he/she can be in dealing with difficult situations he/she faces. 
Similarly, Zimmermann (26) defines self-efficacy as "one's personal judgments about how he / she organizes his / her skills and talents to achieve predetermined goals".

Bandura (4) suggests four main sources to develop self-efficacy in Social Learning Theory. The most effective method is to have direct personal success or failure experiences in daily life. If individuals experience easy achievements while developing their efficacy beliefs, the following failures will easily distort their motivation. The second effective way to develop self-efficacy is indirect experiences inspired by role models. Individuals tend to follow successful models as their idols, and they will feel successful and have a strong feeling of efficacy in their professions thanks to the positive effect of this situation. However, it is also possible to see negative role models, which may result in negative effects. Social and verbal persuasion is the third way to develop self-efficacy beliefs. It is clear that the warnings, suggestions, advice and other comments made by the individuals in nearby social environment in case of achievements and failures will somehow affect the development of self-efficacy beliefs. Physiological emotional state of the individual is the fourth way, and it occurs when others judge his/her abilities. Physiological and emotional states of the individual while displaying behaviors will lead to either achievements or failures. Feeling mentally and physically well will increase the possibility of fulfilling the task or realizing a behavior successfully and boost self-efficacy beliefs, while negative feelings weaken such possibilities (4).

Tschannen - Moran et al. (20) define teacher self-efficacy as "teachers' beliefs about their capacity to affect students' performances". According to another definition, teacher self-efficacy is teachers' beliefs about whether they have the skills needed to fulfill their teaching function; that is, to do their job well (15). Similarly, Caprara et al. (6) defines teacher self-efficacy as "teachers' perceptions regarding the skills they have to help learners reach their goals and to improve teaching quality". Finally, Roos et al. (17) suggest that high levels of teacher self-efficacy may encourage learners to participate in teaching activities and considerably contribute to their attempts to deal with difficulties faced during learning process.

There are many studies focusing on selfefficacy, which is highly emphasized by Social
Learning Theory, and comparing various practices in educational contexts through different scales. While some of these studies are conducted with preservice teachers, others focused on in-service teachers in different educational contexts. Ercan Özaydın et al. (12) conducted a study focusing on the self-efficacy beliefs of pre-service primary school teachers and concluded that they found themselves quite satisfactory in terms of self-efficacy. Demirtaş et al. (8), in their study with the students attending education faculties, found siginificant differences among departments in terms of self-efficacy perception. The following studies also stand out in the related literature:

- a study which compares pre-service physical education and sports teachers with preservice teachers in other branches (18)

- a study conducted with pre-service teachers, in-service teachers and the academic staff teaching at various schools at universities (16)

- a study conducted with in-service teachers of physical education and sports (22)

- a study conducted with in-service teachers of physical education and sports in Nevşehir (25)

- a study comparing self-efficacy scores of inservice teachers of physical education and sports and primary school teachers who later preferred to be physical education and sports teachers.

- a study conducted with in-service teachers physical education and sports (14).

Most of these studies conclude that self-efficacy beliefs of in-service and pre-service teachers are quite high. It is reported that the teachers with high levels of self-efficacy create a reliable and supportive environment for instructional activities, give more importance to active participation of students in classroom activities, take individual differences into consideration and use classroom environment more economically. It can be said that teachers with high level of self-efficacy have better problem solving skills and have the will and willingness to cope with the problems they face. Self-efficacy beliefs of preservice teachers positively affect their perceptions, behaviors, enthusiasm to learn, learning experiences and learning outcomes. In addition, it is important to enrich teaching and learning processes with new experiences and approaches so that they can be quality teachers when they start to work. Finally, Hazır Bikmaz (13) states that teachers with strong 
self-efficacy beliefs are more eager and wellmotivated about teaching and create effective environments for their students to have new experiences.

Thus, this study aims to determine self-efficacy beliefs of pre-service teachers of physical education and sports regarding teaching profession and to examine whether the data obtained vary according to certain variables.

\section{MATERİAL \& METHOD}

\section{Research Design}

The study is a survey study, which is one of the qualitative research designs. The studies aiming to collect data about the characteristics of a particular group are called survey study (5).

\section{Participants}

The participants of the study include 526 university students (222 female and 304 male) who attend the Physical Education and Sports Teaching Departments of the following universities: Afyon Kocatepe University (60); Cumhuriyet University (48); Dumlupınar University (103); Kastamonu University (110); Pamukkale University (90); and Gazi University (115). They participated in the study on a volunteer basis. Of these 526 participants, 129 were 1st year students, 102 2nd year, 138 3rd year and 1574 th year students.

\section{Data Collection Tools}

Demographic Information Form: Developed by the researchers, this form includes questions aiming to obtain the following information about the participants: age, gender, the university they attend, class level, family income level, and educational background of parents.

Teacher Self-efficacy Scale: The study used "Teacher Self-efficacy Scale", which was developed by Tschannen-Moran and Woolfolk Hoy (21) and adapted to Turkish context by Çapa et al. (7) with a study conducted by 628 pre-service teachers from 6 different universities. The scale consists of 24 items grouped under three dimensions; namely "student participation", "educational strategies" and "classroom management". The Crombach Alpha values for the dimensions change between .82 and .84 .

\section{Data Analysis}

The data obtained from the participants was analyzed by using SPSS 22 software. Normal distribution was checked by using KolmogorovSmirnov test for each variable. The results showed that the data did not show a normal distribution, so the researchers decided to apply non-parametical tests; Kruskal Wallis Test for university and class level variables; Mann Whitney-U test for age and gender variables. As for the calculation of internal reliability, Cronbach Alpha analysis was used. Since each independent variable was tested for the three dimensions of the scale, Bonferroni correction was applied. Accordingly, the new critical alpha level for Kruskal Wallis tests was determined as .0167.

\section{INTERPRETATION of ANALYSIS \& FINDINGS}

Cronbach Alpha internal reliability results for the dimensions of Teacher Self-efficacy Scale are displayed in Table 1 below.

Table 1. Cronbach Alpha Values regarding the Dimensions of Teacher Self-efficacy Scale

\begin{tabular}{lc}
\hline \multicolumn{1}{c}{ Dimensions } & Cronbach Alpha \\
\hline Student Participation & 0.875 \\
\hline Educational Strategies & 0.883 \\
\hline Classrom Management & 0.888 \\
\hline
\end{tabular}

According to Table 1, Cronbach Alpha internal reliability results for the dimensions of Teacher Self-efficacy Scale range between ,875 and ,888. These values prove that the study is highly reliable (2).

Table 2 below shows Kruskal Wallis Test results for the dimensions of Teacher Self-efficacy Scale in terms of "university" variable. 
Table 2. Kruskal Wallis Test Results accordng to the "University" Variable

\begin{tabular}{|c|c|c|c|c|c|c|}
\hline Sub-Dimensions & Universities & $\mathrm{N}$ & $\begin{array}{l}\text { Mean } \\
\text { Rank }\end{array}$ & Sd & $\chi^{2}$ & $\begin{array}{c}\text { Multiple } \\
\text { Comparison }\end{array}$ \\
\hline \multirow{6}{*}{ Student Participation } & 1) Afyon Kocatepe Uni. & 60 & 240.11 & \multirow{6}{*}{5} & \multirow{6}{*}{12.575} & \multirow{6}{*}{-} \\
\hline & 2) Cumhuriyet Uni. & 48 & 323.80 & & & \\
\hline & 3) Dumlupınar Uni. & 103 & 257.22 & & & \\
\hline & 4) Kastamonu Uni. & 110 & 280.37 & & & \\
\hline & 5) Pamukkale Uni. & 90 & 241.76 & & & \\
\hline & 6 ) Gazi Uni. & 115 & 257.04 & & & \\
\hline \multirow{6}{*}{ Educational Strategies } & 1) Afyon Kocatepe Uni. & 60 & 248.64 & \multirow{6}{*}{5} & \multirow{6}{*}{9.382} & \multirow{6}{*}{-} \\
\hline & 2) Cumhuriyet Uni. & 48 & 309.07 & & & \\
\hline & 3) Dumlupınar Uni. & 103 & 265.63 & & & \\
\hline & 4) Kastamonu Uni. & 110 & 278.00 & & & \\
\hline & 5) Pamukkale Uni. & 90 & 234.06 & & & \\
\hline & 6 ) Gazi Uni. & 115 & 259.50 & & & \\
\hline \multirow{7}{*}{ Classrom Management } & 1) Afyon Kocatepe Uni. & 60 & 237.83 & \multirow{6}{*}{5} & \multirow{6}{*}{$23.443^{*}$} & \multirow{6}{*}{$4-5$} \\
\hline & 2) Cumhuriyet Uni. & 48 & 315.55 & & & \\
\hline & 3) Dumlupinar Uni. & 103 & 268.16 & & & \\
\hline & 4) Kastamonu Uni. & 110 & 304.74 & & & \\
\hline & 5) Pamukkale Uni. & 90 & 227.99 & & & \\
\hline & 6 ) Gazi Uni. & 115 & 239.16 & & & \\
\hline & Total & 526 & & & & \\
\hline
\end{tabular}

${ }^{*} \mathrm{p}<.0167$ (Critical alpha level was determined as .0167 after the Bonferroni correction)

According to Table 2, there is a statistically significant difference among universities in terms of classroom management dimension $(\chi 2=23.443$; $\mathrm{p}=0.000$; $\eta 2=0.044)$. The results of the Kruskal Wallis multiple comparison test applied through Bonferroni correction reveal that Kastamonu University students have higher self-efficacy levels than Pamukkale University students in terms of "classroom management" $(p=0.006)$

Table 3. Kruskal Wallis Test Results according to Class Level

\begin{tabular}{|c|c|c|c|c|c|c|}
\hline Sub-Dimensions & Class & $\mathrm{N}$ & $\begin{array}{l}\text { Mean } \\
\text { Rank }\end{array}$ & $\mathrm{sd}$ & $\chi^{2}$ & $\mathrm{p}$ \\
\hline \multirow{4}{*}{ Student Participation } & $1^{\text {st }}$ Year & 129 & 265.34 & \multirow{4}{*}{3} & \multirow{4}{*}{3.864} & \multirow{4}{*}{0.277} \\
\hline & $2^{\text {nd }}$ Year & 102 & 248.89 & & & \\
\hline & $3^{\text {rd }}$ Year & 138 & 283.16 & & & \\
\hline & $4^{\text {th }}$ Year & 157 & 254.20 & & & \\
\hline \multirow{4}{*}{ Educational Strategies } & $1^{\text {st }}$ Year & 129 & 256.80 & \multirow{4}{*}{3} & \multirow{4}{*}{2.041} & \multirow{4}{*}{0.564} \\
\hline & $2^{\text {nd }}$ Year & 102 & 252.08 & & & \\
\hline & $3^{\text {rd }}$ Year & 138 & 277.74 & & & \\
\hline & $4^{\text {th }}$ Year & 157 & 263.91 & & & \\
\hline \multirow{4}{*}{ Classrom Management } & $1^{\text {st }}$ Year & 129 & 262.19 & \multirow{4}{*}{3} & \multirow{4}{*}{0.151} & \multirow{4}{*}{0.985} \\
\hline & $2^{\text {nd }}$ Year & 102 & 267.96 & & & \\
\hline & $3^{\text {rd }}$ Year & 138 & 264.45 & & & \\
\hline & $4^{\text {th }}$ Year & 157 & 260.85 & & & \\
\hline & Total & 526 & & & & \\
\hline
\end{tabular}

As shown in Table 3, the analysis of Teacher Self-efficacy Scale dimensions did not reveal a statistically significant difference among the groups ( $>00.0167)$. 
Table 4. Mann Whitney U Test Results according to the Age of the Participants

\begin{tabular}{|c|c|c|c|c|c|c|c|}
\hline $\begin{array}{c}\text { Sub- } \\
\text { Dimensions }\end{array}$ & Age Groups & $\mathrm{N}$ & $\begin{array}{l}\text { Mean } \\
\text { rank }\end{array}$ & Sum of Ranks & $\mathrm{Z}$ & $\mathrm{U}$ & $\mathrm{p}$ \\
\hline Student & $17-22$ & 401 & 259.00 & 103859.00 & \multirow{2}{*}{-0.523} & \multirow{2}{*}{23258.00} & \multirow{2}{*}{0.224} \\
\hline Participation & 23 and above & 125 & 277.94 & 34742.00 & & & \\
\hline Educational & $17-22$ & 401 & 259.16 & 103923.00 & \multirow{2}{*}{-1.217} & \multirow{2}{*}{23322.00} & \multirow{2}{*}{0.240} \\
\hline Strategies & 23 and above & 125 & 277.42 & 34678.00 & & & \\
\hline Classrom & $17-22$ & 401 & 261.57 & 104888.00 & \multirow{2}{*}{-1.174} & \multirow{2}{*}{24287.00} & \multirow{2}{*}{0.601} \\
\hline Management & 23 and above & 125 & 269.70 & 33713.00 & & & \\
\hline
\end{tabular}

According to Table 4, dimension scores for Teacher Self-efficacy Scale did not differ significantly according to "age" variable ( $\mathrm{p}>.05)$.

Table 5. Mann Whitney U Test Results according to the Gender of the Participants

\begin{tabular}{|c|c|c|c|c|c|c|c|}
\hline $\begin{array}{c}\text { Sub- } \\
\text { Dimensions } \\
\end{array}$ & Gender & $\mathrm{N}$ & $\begin{array}{l}\text { Mean } \\
\text { Rank } \\
\end{array}$ & Sum of Ranks & $\mathrm{Z}$ & $\mathrm{U}$ & $\mathrm{p}$ \\
\hline \multirow{2}{*}{$\begin{array}{c}\text { Student } \\
\text { Participation }\end{array}$} & Female & 222 & 259.11 & 57522.00 & \multirow{2}{*}{-0.571} & \multirow{2}{*}{32769.00} & \multirow{2}{*}{0.571} \\
\hline & Male & 304 & 266.71 & 81079.00 & & & \\
\hline \multirow{2}{*}{$\begin{array}{c}\text { Educational } \\
\text { Strategies }\end{array}$} & Female & 222 & 263.92 & 58590.50 & \multirow{2}{*}{-0.054} & \multirow{2}{*}{33650.50} & \multirow{2}{*}{0.957} \\
\hline & Male & 304 & 263.19 & 80010.50 & & & \\
\hline \multirow{2}{*}{$\begin{array}{c}\text { Classrom } \\
\text { Management }\end{array}$} & Female & 222 & 259.02 & 57503.50 & \multirow{2}{*}{-0.567} & \multirow{2}{*}{32750.50} & \multirow{2}{*}{.564} \\
\hline & Male & 304 & 266.77 & 81097.50 & & & \\
\hline
\end{tabular}

Table 5 clearly shows that dimension scores for Teacher Self-efficacy Scale did not differ

\section{CONCLUSION \& EVALUATION}

This study aims to examine self-efficacy levels of pre-service teachers attending departments of physical education and sports teaching in sports science faculties and schools of sports according to certain variables such as school, class level, gender and age. For the purposes of the study, 526 preservice teachers from 7 different universities were included in the study as the participants.

According to the statistical analyses for "university" variable, there is not a meaningful difference for "Student Participation" and "Educational Strategies" dimensions, but there is a meaningful difference for "Classroom Management" one $(\mathrm{p}<.05)$. Cumhuriyet University has the highest percentage in "Classroom Management" dimension while Pamukkale University the lowest. However, a meaningful difference was found for Kastamonu University and Pamukkale University. It is believed that insufficient sampling for Cumhuriyet University might have caused this situation. The meaningful differences among the groups might be due to different locations of universities and the reasons for preferring them. When we consider the fact that approximately 30 students enroll Pamukkale University in an academic year, we can significantly according to "gender" variable ( $\mathrm{p}>0.05)$.

conclude that the university is more demanding and meticulous in its student selection exams, so the applicants are expected to be more motivated to attend the department. In addition, low number of students in classrooms is expected to increase the quality and productivity of education. However, the low self-efficacy belief scores for the students attending such faculties seems to be an unexpected consequence.

The statistical analyses made for class level variable revealed no significant difference for any dimension ( $p>$.05). However, it was found that the highest mean score for student participation and educational strategies dimensions was for 3rd year students and for classroom management dimension 2nd year students. Alemdağ et al. (1), in their study conducted with pre-service physical education and sports teachers, found a meaningful difference in total scores for class level variable. They also found that the highest percentage was for 3rd year students and the lowest for 2nd year. This situation is similar to the results of student participation and educational strategies dimensions of this study. Mirzeoğlu et al. (16) compared 1st year and 4th year students in their study and found that 1st year students had higher self-efficacy scores. In our study, 1st year students obtained the highest score 
only for student participation dimension. Ekinci (9) conducted a study with 2 nd, 3rd and 4th year preservice teachers of muic, painting and physical education. According to the findings, there was no meaningful difference for class level variable and 3rd year pre-service teachers have the highest means scores. The results for student participation and educational strategies dimensions are similar to our study. The study conducted by Yenice (24) with preservice teachers from different branches did not reveal any significant differences for class level variable. It is interesting that 4 th year pre-service teachers have lower mean scores than 3rd year students although there was not a meaningful difference between these groups. The reason for this situation might be that 4th year students had the chance to have teaching experience in School Experience and Practice Teaching courses and did not find themselves sufficient in their teaching experiences, which caused a decrease in their selfefficacy scores.

While self-efficacy beliefs of pre-service teachers of physical education and sports do not show a meaningful difference for gender variable, males participants obtained higher scores for student participation and Classroom management dimensions and female participants for educational strategies dimension. While some of the studies conducted with pre-service and in-service teachers of physical education and sports found no meaningful difference for gender variable $(18,1,16$, $9)$, others found a significant difference for the same variable $(14,25,11)$. Although some studies conducted with pre-service and in-service teachers from different branches found meaningful differences for gender variable $(10,8,22)$, others found no difference just like in our study for the same variable $(24,23,12)$.

The examination of self-efficacy scores according to "age" variable did not reveal statistically meaningful differences for the age groups "17-22" and "23 and above" although the mean scores of the participants in "23 and above" group were relatively higher. Thus, it can be concluded that as the age increases, self-efficacy beliefs also increase. Self-efficacy beliefs of preservice teachers are known to affect their perceptions, behaviors, willingness to learn, experiences and learning outcomes. Thus, enriching teaching-learning process with more effective, productive new practices and approaches is gaining more and more importance while training qualified teachers of the future.

In conclusion, it is known that similar studies have been conducted with pre-service and in-service teachers from different branches. This study focused on pre-service teachers of physical education and sports and examined their self-efficacy beliefs in terms of university, class level, gender and age variable. No meaningful difference was found for class level, gender and age variables. The results obtained are consistent with those of many similar studies although some conflicting results were also obtained. This study found meaningful difference for university variable in classroom management dimension. Including university variable is the main difference of this study from the similar ones. It is believed that conducting more studies focusing on various branches and universities from different geographical locations will considerably contribute to the increasing quality of teacher training institutions, organizations and their students.

\section{REFERENCES}

1. Alemdağ C, Öncü E, Yılmaz AK. Beden eğitimi öğretmeni adaylarının akademik motivasyon ve akademik özyeterlikleri. Spor Bilimleri Dergisi, 2014; 25(1): 23-35.

2. Alpar R. Spor, Sağlık ve Eğitim Bilimlerinde Örneklerle Uygulamalı İstatistik ve Geçerlik - Güvenirlik. Ankara: Detay Yayıncilık, 2010; 349.

3. Bandura A. Self-efficacy: Toward a unifying theory of behavioral change. Psychological Review, 1977; 84(2): 191215.

4. Bandura A. Self-efficacy. Encyclopedia of Human Behavior. New York: Academic Press, 1994; 4: 71-81

5. Büyüköztürk Ş, Çakmak EK, Akgün ÖE, Karadeniz Ş, Demirel F. Bilimsel Araştırma Yöntemleri. 9. Baskı. Ankara: Pegem Akademi, 2011; 16.

6. Caprara GV, Barbaranelli C, Steca P, Malone PS. Teachers' self-efficacy beliefs as determinants of job satisfaction and students' academic achievement: A study at the school level. Journal of School Psychology, 2006; 44(6), 473-490.

7. Çapa Y, Çakıroğlu J, Sarıkaya H. The development and validation of a turkish version of the teachers' sense of efficacy scale. Eğitim ve Bilim, 2005; 30 (137): 74-81.

8. Demirtaş H, Cömert $M$, Özer N. Öğretmen adaylarının özyeterlik inançları ve öğretmenlik mesleğine ilişkin tutumları. Eğitim ve Bilim, 2011;36(159): 96-111.

9. Ekinci H. Öğretmen adaylarının özyeterlik algılarının karşılaştırılması; Müzik, resim ve beden eğitimi. Turkish Studies, 2013; 8(3): 189-196.

10. Elkatmış $M$, Demirbaş $M$, Ertuğrul N. Eğitim fakültesi öğrencileri ile formasyon eğitimi alan fen edebiyat fakültesi öğrencilerinin öğretmenlik mesleğine yönelik öz yeterlik inançları. Pegem Eğitim ve Öğretim Dergisi, 2013; 3(3): 41-50. 
11. Erdoğan $\mathrm{H}$, Bahadır Z. Beden eğitimi öğretmenleri ile sınıf öğretmenliğinden geçiş yapan beden eğitimi öğretmenlerinin yeterlik algılarının incelenmesi. Niğde Üniversitesi Beden Eğitimi ve Spor Bilimleri Dergisi, 2016; 10(3): 405-415.

12. Ercan Özaydın T, Çavaş P, Arslan Cansever, B. Sınıf öğretmeni adaylarının özyeterlik inançlarının değerlendirilmesi. Ege Eğitim Dergisi, 2017; 1(18): 1-30.

13. Hazır Bıkmaz F. Sınıf öğretmenlerinin fen öğretiminde öz yeterlilik inancı ölçeğinin geçerlik ve güvenirlik çalışması. Milli Eğitim Dergisi, 2004; 161.

14. Kafkas ME, Çoban B, Karademir T. Beden eğitimi öğretmen adaylarının öz-yeterlik algıları ile mesleki kaygılar arasındaki ilişki. İnönü Üniversitesi Eğitim Fakültesi Dergisi, 2010; 11(2): 93-111.

15. Kurt T. Öğretmenlerin öz yeterlik ve kolektif yeterlik algıları. Türk Eğitim Bilimleri Dergisi, 2012; 10(2): 195-227.

16. Mirzeoğlu D, Aktağ I, Boşnak M. Beden eğitimi öğretmeni, öğretmen adayı ve beden eğitimi ve spor yüksekokullarında görev yapan öğretim elemanlarının mesleki yeterlik duygusunun karşılaştırılması. Spor Bilimleri Dergisi, 2007, 18(3): 109-125.

17. Ross JA, Hogaboam-Gray A, Hanna L. Effects of teacher efficacy on computer skills and computer cognitions of Canadian students in grades K-3. The Elementary School Journal, 2001; 102(2): 141-156.

18. Sandıkçı M, Öncü E. Beden eğitimi ile diğer alanlardaki öğretmen adaylarının öğretmenlik mesleğine ilişkin yeterlik algıları ve tutumlarının belirlenmesi ve karşılaştırılması. Pamukkale Spor Bilimleri Dergisi, 2013; 4(1): 135-151.

19. Senemoğlu N. Gelişim Öğrenme ve Öğretim. Ankara: Gazi Kitabevi, 2002; 235.

20. Tschannen-Moran M, Hoy AW, Hoy WK. Teacher efficacy: Its meaning and measure. Review of Educational Research, 1998; 68(2): 202-248.

21. Tschannen-Moran M, Hoy AW. Teacher efficacy: Capturing an elusive construct. Teaching and Teacher Education, 2001; 17(7): 783-805.

22. Turan MB, Pepe $O$, Bahadır Z. Investigating self-efficacy levels of physical education and sports teachers in terms of some variables. Science, Movement and Health, 2015; 15(2): 158-163.

23. Üstüner $M$, Demirtaş $H$, Cömert $M$, Özer N. Ortaöğretim öğretmenlerinin özyeterlik algıları. Mehmet Akif Ersoy Üniversitesi Eğitim Fakültesi Dergisi, 2009; 9(17): 1-16.

24. Yenice N. Öğretmen adaylarının öz-yeterlik düzeyleri ile problem çözme becerilerinin incelenmesi. Elektronik Sosyal Bilimler Dergisi, 2012; 11(39): 36-58.

25. Yılmaz G, Yılmaz B, Türk N. Beden eğitimi ve spor öğretmenlerinin mesleklerine ilişkin öz yeterlik düzeylerinin incelenmesi (Nevşehir İli Örneği). Selçuk Üniversitesi Beden Eğitimi ve Spor Bilim Dergisi, 2010; 12(2): 85-90.

26. Zimmerman BJ. Self-efficacy: An essential motive to learn. Contemporary Educational Psychology, 2000; 25(1): 8291. 